\title{
INOVASI MODEL PENGEMBANGAN KEBIJAKAN EKONOMI KREATIF PROVINSI BANTEN
}

Ahmad Sururi

Program Studi Administrasi Negara Fakultas Ilmu Sosial dan Politik

Universitas Serang Raya

\begin{abstract}
Abstrak
Dimensi Ekonomi kreatif di Provinsi Banten sampai dengan saat ini belum menunjukkan perkembangan yang diharapkan. Berbagai penyebab belum berkembangnya potensi dan sumber daya ekonomi kreatif di Provinsi Banten adalah karena belum terbangunnya struktur industri yang menopang pengembangan ekonomi kreatif, belum tersedianya skema pembiayaan bagi pelaku industri ekonomi kreatif, terbatasnya akses pemasaran ekonomi kreatif dan belum optimalnya support kelembagaan ekonomi kreatif (sinergitas pemerintah, komunitas kreatif, dunia usaha dan akademisi).

Tujuan penelitian ini adalah untuk mendeskripsikan potensi ekonomi kreatif Provinsi Banten terutama dari aspek ekspor produk-produk ekonomi kreatif, deskripsi peluang dan tantangan ekonomi kreatif di Banten dan studi analisis model kebijakan inovasi pengembangan ekonomi kreatif Provinsi Banten.

Metode Penelitian menggunakan penelitian kebijakan dan pendekatan yang digunakan dalam penelitian ini adalah pendekatan kualitatif. Penelitian ini juga bersifat deskriptif analitis karena penelitian tidak hanya terbatas pada deskripsi mengenai objek kajian akan tetapi juga melakukan analisis.

Hasil dan simpulan menunjukkan Provinsi Banten memiliki modal dan potensi dari besaran ekspor produk-produk ekonomi kreatif, terdapat peluang-peluang yang dapat dimanfaatkan dan tantangan-tantangan dan perlunya penguatan sinergitas antara berbagai aktor ekonomi kreatif yaitu masyarakat, pemerintah, akademisi/intelektual, pelaku bisnis dan komunitas kreatif dalam mendorong pengembangan ekonomi kreatif di Provinsi Banten melalui sebuah inovasi model pengembangan kebijakan ekonomi kreatif.
\end{abstract}

Kata Kunci : Inovasi Kebijakan, Ekonomi Kreatif

\begin{abstract}
The dimension of creative economy in Provinsi Banten to date has not shown the expected growth. The reasons for the lack of potential and creative economic resources in Provinsi Banten are the lack of development of industrial structures that support the development of creative economy, the lack of financing schemes for creative industries, limited access to creative economy marketing and the lack of optimum institutional support for creative economy (government synergy Creative communities, businesses and academics).

The purpose of this study is to describe the creative economic potential of Provinsi Banten, especially from the export aspects of creative economy products, descriptions of opportunities and challenges of creative economy in Banten and the study of policy analysis model of innovation of creative economy development of Provinsi Banten.

Research method using policy research and approach used in this research is qualitative approach. This research is also analytical descriptive because the research is not only limited to the description of the object of the study but also the analysis.

The results and conclusions show that the Provinsi Banten has capital and potential of export products of creative economy, there are opportunities that can be utilized and challenges and the need to strengthen the synergy between creative economic actors such as society, government, academic / intellectual, business And creative community in encouraging the development of creative economy in Provinsi Banten through an innovative model of creative economic policy development.
\end{abstract}

Keywords: Policy Innovation, Creative Economy 


\section{A. Pendahuluan}

Era globalisasi dan konektivitas sosial ekonomi mengubah cara bertukar informasi dan konsumsi dari produk-produk budaya dan teknologi yang berasal dari berbagai tempat di belahan dunia. Dunia menjadi tempat yang sangat dinamis dan kompleks sehingga kreativitas dan pengetahuan menjadi suatu aset yang tak ternilai dalam era kompetitif dan perkembangan perekonomian suatu negara Disisi lain era persaingan perdagangan bebas antara negara mengharuskan setiap negara untuk berupaya meningkatkan kualitas perekonomiannya agar dapat bersaing baik di pasar dalam negeri maupun luar negeri. Dengan demikian menjadi sebuah keniscayaan bagi suatu negara dan daerah untuk terus berupaya mendorong perekonomian dengan berbagai pengembangan gagasan dan peningkatan kualitas sumber daya manusia melalui ekonomi kreatif sebagai lokomotive perekonomiannya.

Peran penting ekonomi kreatif di Indonesia diwujudkan dalam Peraturan Presiden Nomor 72 Tahun 2015 Tentang Perubahan Atas Peraturan Presiden Nomor 6 Tahun 2015 Tentang Badan Ekonomi Kreatif yang terdiri atas 16 sub-sektor, yaitu : (1) Arsitektur; (2) Desain interior; (3) Desain Komunikasi Visual; (4) Desain Produk; (5) Film, animasi dan video; (6) Fotografi; (7) Kriya; (8) Kuliner; (9) Musik; (10) Fashion; (11) Aplikasi dan game developer; (12) Penerbitan; (13) Periklanan; (14) Televisi dan radio; (15) Seni pertunjukan; dan (16) Seni rupa. Dengan demikian pengembangan setiap daerah atau provinsi di Indonesia untuk menjadikan peran penting ekonomi kreatif perlu diupayakan secara intensif. Oleh sebab itu diperlukan pengembangan ekonomi kreatif bagi suatu daerah termasuk dalam hal ini Provinsi Banten untuk menjawab tantangan permasalahan pembangunan diantaranya pertumbuhan ekonomi yang relatif konstan atau bahkan cenderung rendah, tingkat

Pertumbuhan Ekonomi (\%)

\begin{tabular}{|c|c|c|}
\hline Tahun & Banten & Nasional \\
\hline 2012 & 6.83 & 6.03 \\
\hline 2013 & 6.67 & 5.56 \\
\hline 2014 & 5.47 & 5.02 \\
\hline 2015 & 5.37 & 4.79 \\
\hline 2016 & 5.26 & 5.02 \\
\hline
\end{tabular}

Sumber : BPS, 2017

Dalam konteks ekonomi kreatif, pengembangan kota kreatif menjadi salah satu upaya dalam mendorong daya saing perekonomian yang berkelanjutan. Oleh sebab itu upaya kemiskinan dan pengangguran yang masih tinggi, dan daya saing industri kreatif yang masih rendah.

Ekonomi kreatif memerlukan faktor kreatifitas sebagai instrumen utama. Dan kreatifitas harus dibangun melalui sebuah konsep yang memberikan space bagi tumbuhnya komunitas kreatif. Bahwa ekonomi kreatif adalah sebuah konsep yang menempatkan kreativitas dan pengetahuan sebagai aset utama dalam menggerakkan ekonomi. Konsep ini telah memicu ketertarikan berbagai negara untuk melakukan kajian seputar Ekonomi Kreatif dan menjadikan Ekonomi Kreatif model utama pengembangan ekonomi. Indonesia Kreatif. (2013). Creative Economy. Retrieved From http://indonesiakreatif.net/creative-economy.

Sasaran kebijakan ekonomi kreatif Provinsi Banten disusun dengan tetap berpedoman pada arah kebijakan pembangunan ekonomi Provinsi Banten yang telah tercantum dalam RPJMN 2015-2019, RPJMD Provinsi Banten tahun 2012-2017 dan RPJPD Provinsi Banten tahun 2005-2005. Akan tetapi kebijakan tersebut belum dilakukan secara terintegrasi sehingga belum optimal menumbuhkembangkan potensi ekonomi kreatif di Provinsi Banten. Sebagai sebuah konsep yang berbasis pada pengembangan sumber daya manusia, ekonomi kreatif bertransformasi menjadi sebuah opsi dalam meningkatkan kualitas pertumbuhan dan pemerataan ekonomi suatu daerah. Kesenjangan wilayah kota dan kabupaten di Provinsi Banten yang tidak merata dari aspek pertumbuhan ekonomi dan kesejahteraan menjadi permasalahan yang menyebabkan belum signifikannya pertumbuhan ekonomi Banten. Dari kurun waktu tahun 2014 hingga tahun 2016 dapat terlihat pertumbuhan ekonomi dan PDRB Perkapita Provinsi Banten masih berada di bawah rata-rata tingkat nasional.

PDRB Perkapita (Ribu/Jiwa)

\begin{tabular}{|c|c|c|}
\hline Tahun & Banten & Nasional \\
\hline 2012 & 29.977 & 32.364 \\
\hline 2013 & 30.202 & 35.105 \\
\hline 2014 & 32.992 & 38.366 \\
\hline 2015 & 36.606 & 41.900 \\
\hline 2016 & 39.997 & 45.176 \\
\hline
\end{tabular}

Sumber : BPS, 2017

menciptakan kota dan kabupaten kreatif di Provinsi Banten melalui model kebijakan yang komprehensif dapat menjadi opsi dalam mengatasi kesenjangan wilayah. Keberagaman potensi lokal 
yang tersebar di Kota-kota Provinsi Banten dapat menjadi modal material dan sosial dalam mengembangkan kota dan kabupaten kreatif. Dengan demikian akan tercipta kota dan kabupaten dengan tingkat daya saing yang kompetitif.

Permasalahan tingkat kemiskinan yang tinggi di Banten sebesar 5,75\% pada tahun 2015 dan 5,36\% pada tahun 2016, kemudian dengan tingkat pengangguran terbuka di Provinsi Banten pada tahun 2015 sebesar 9,55\% dan pada tahun 2016 sebesar 8,92\% (Kondisi Eksisting Provinsi Banten dalam Rancangan RPJMD Provinsi Banten yang dipaparkan Gubernur Banten, 2017), kemudian berdasarkan data survey Khusus Ekonomi Kreatif (SKEK) tahun 2016 disebutkan bahwa pada tahun 2014 terdapat sebanyak 15.167.573 adalah penduduk yang bekerja di sektor ekonomi kreatif dari jumlah 114.628.026 penduduk Indonesia yang bekerja. Hal tersebut menunjukkan bahwa daya industri ekonomi kreatif dalam menampung tenaga kerja cukup tinggi sehingga dapat menekan tingkat pengangguran dan kemiskinan.

Selain itu penyebab belum berkembangnya potensi dan sumber daya ekonomi kreatif di Provinsi Banten adalah karena belum terbangunnya struktur industri yang menopang pengembangan ekonomi kreatif dan belum tersedianya skema pembiayaan bagi pelaku industri ekonomi kreatif. Kondisi tersebut diikuti dengan terbatasnya akses pemasaran ekonomi kreatif dan belum optimalnya support kelembagaan ekonomi kreatif (sinergitas pemerintah, komunitas kreatif, dunia usaha dan akademisi). Beberapa permasalahan tersebut disebabkan karena belum optimalnya model kebijakan yang terintegrasi dalam mendukung pengembangan ekonomi kreatif di Provinsi Banten.

Tujuan penelitian ini adalah untuk mendeskripsikan potensi ekonomi kreatif Provinsi Banten terutama dari aspek ekspor produk-produk ekonomi kreatif, deskripsi peluang dan tantangan ekonomi kreatif di Banten dan studi analisis model kebijakan inovasi pengembangan ekonomi kreatif Provinsi Banten.

\section{B. Landasan Teoretis}

\section{Kebijakan Publik, Inovasi Kebijakan dan Model Kebijakan.}

Kebijakan publik dimaknai sebagai serangkaian tindakan yang dipilih dan dialokasikan secara sah oleh pemerintah/negara kepada seluruh anggota masyarakat yang mempunyai tujuan tertentu demi kepentingan publik. (Islami, 1988). Pernyataan tersebut bermakna bahwa terdapat action dari pemerintah terhadap publik yang bersifat legal dan diakui sebagai kekuasaan politik sekaligus bentuk pertanggungjawaban pemerintah dalam melindungi kepentingan publik. Dalam konteks pemerintah, dapat disimpulkan bahwa kebijakan publik merupakan segala sesuatu yang dikerjakan pemerintah, mengapa mereka melakukan dan hasil yang membuat sebuah kehidupan bersama tampil berbeda. (Thomas R Dye, 1992 dalam Ryan Nugroho, 2004:3)

Inovasi diartikan sebagai suatu ide, produk, informasi teknologi, kelembagaan, perilaku, nilainilai, dan praktek-praktek baru atau objek-objek yang dapat dirasakan sebagai sesuatu yang baru oleh individu atau masyarakat. Rogers (1995) dalam Lydia Wijayanti (2012). Paradigma dan konsep inovasi kebijakan publik telah menjadi diskursus dan praktek dalam birokrasi pemerintahan. Dalam konteks tersebut, kebijakan publik dapat dipandang sebagai suatu proses yang berkesinambungan dan saling terkait yang dilakukan oleh pemerintah bersama stakeholder dalam mengatur, mengelola dan menyelesaikan urusan publik, masalah publik dan sumber daya yang ada untuk kepentingan bersama (Deddy Mulyadi, 2015).

Secara konseptual, inovasi kebijakan publik terbagi menjadi a). Policy innovation: new policy direction and initiatives yaitu inovasi kebijakan yang dimaksud adalah adanya inisiatif dan arah kebijakan baru. Ini dapat diartikan bahwa setiap kebijakan publik yang dikeluarkan pada prinsipnya harus dapat memuat sesuatu yang baru. b). Innovation in the policy making process. Pada peranan ini, yang menjadi fokus adalah inovasi yang dapat memengaruhi proses pembuatan atau perumusan kebijakan. Sebagai contoh adalah proses perumusan kebijakan yang selama ini belum dapat dikatakan telah memfasilitasi peran serta warga masyarakat atau stakeholders terkait. c). Policy to foster innovation and its diffusion, yaitu kebijakan yang dimaksud adalah kebijakan yang khusus diciptakan untuk mendorong, mengembangkan, dan menyebarkan inovasi untuk berbagai sektor Albury (2003).

Model kebijakan adalah representasi sederhana mengenai aspek-aspek yang dipilih dari suatu kondisi masalah yang disusun untuk tujuantujuan tertentu. Model kebijakan merupakan penyederhanaan sistem masalah dengan membantu mengurangi kompleksitas dan menjadikannya dapat dikelola oleh para analis kebijakan (Dunn, 2003:233. Terdapat sejumlah model kebijakan publik yang dikemukakan oleh 
para ahli antara lain : Model Institusional, Model Kelompok, Model Sistem-Politik, Model Elit Massa,Model Rational-Comprehensive, Model Incremental, Model Mixed-Scanning, Model Jejaring Kebijakan (Islami, 2000:37).

Definisi jejaring kebijakan dikemukakan oleh Carlsson dan Sanstrom (2008), yaitu sebagai sistem jejaring pemerintahan, dimana berbagai macam tipe aktor, yang terstrukturkan dalam berbagai macam institusi saling berpartisipasi dalam pengambilan keputusan. Dalam hal ini aktor-aktor yang terlibat dan berpartisipasi terstruktur dalam sistem pemerintahan. Sedangkan dalam konsep yang berbeda disebutkan bahwa jejaring kebijakan adalah sistem yang terdiri atas sekumpulan aktor, hubungan dan batasannya. Ia terdiri atas institusi publik dan juga pihak swasta, sementara hubungan yang terjadi diantara aktoraktor tersebut berperan sebagai jalur komunikasi, pertukaran informasi, keahlian (expertise), kepercayaan dan autoritas penggunaan sumber daya alam. (Kenis, P and Schneider, V, 1991)

\section{Memahami Konsep Ekonomi Kreatif}

Pemahaman tentang konsep ekonomi kreatif sudah sering diuraikan oleh berbagai ahli baik secara teoritis maupun empiris. Pada umumnya terdapat kesamaan perspektif tentang makna dan konsep ekonomi kreatif. Dan berikut akan diuraikan beberapa pendapat tentang ekonom kreatif.

UNCTAD dalam Creative Economy Report, (2008:3), menyatakan bahwa "Creativity in this context refers to the formulation of new ideas and to the application of these ideas to produce original works of art and cultural products, functional creation, observable in the way it contributes to entreupreneurship, fosters innovation, enchaces productivity and promotes economic growth. Konsep ekonomi kreatif adalah sebuah konsep ekonomi di era global yang mengintensifkan informasi dan kreativitas dengan mengandalkan ide, gagasan dan stock of knowledge dari Sumber Daya Manusia (SDM) sebagai faktor produksi utama dalam kegiatan ekonominya.

Adalah John Howkins yang memperkenalkan istilah "Ekonomi Kreatif" dalam buku "The Creative Economy: How People Make Money from Ideas" (2001). Howkins menyadari lahirnya gelombang ekonomi baru berbasis kreativitas setelah melihat pada tahun 1997 Amerika Serikat menghasilkan produk-produk Hak Kekayaan Intelektual (HKI) senilai 414 miliar dollar yang menjadikan HKI ekspor nomor
1 Amerika Serikat. Howkins dengan ringkas mendefinisikan ekonomi kreatif, yaitu "The creation of value as a result of idea". (http://indonesiakreatif.bekraf.go.id). Sedangkan United Nations Conference on Trade and Development (UNCTAD) menyebutkan bahwa : "Creativity in this context refers to the formulation of new ideas and to the application of these ideas to produce original works of art and cultural products, functional creation, observable in the way it contributes to entreupreneurship, fosters innovation, enchaces productivity and promotes economic growth.

Dari berbagai penelitian terdahulu mengenai pengembangan ekonomi kreatif yang dilakukan oleh Herie Saksono 2012 : 98 disimpulkan bahwa ekonomi kreatif merupakan talenta/(ide kreatif dan inovatif) dengan nilai ekonomi yang mampu merubah kualitas hidup manusia menjadi lebih sejahtera. Bahwa terdapat tantangan yang harus diatasi dalam mengembangkan ide, kreatif dan inovatif sebagai instrumen penting ekonomi kreatif. Meskipun ekonomi kreatif dianggap sebagai alternatif solusi permasalahan perekonomian akan tetapi dalam penyelenggaraannya masih menemui berbagai hambatan terutama dalam melihat sejauhmana kreatifitas mampu memicu daya saing daerah dan daya saing nasional Peluang Indonesia dalam pengembangan ekonomi kreatif yang meliputi bonus demografi hingga tahun 2025, perkembangan gaya hidup digital, peningkatan jumlah kelas menengah, neningkatnya permintaan produk kreatf dam potensi kekayaan alam budaya (Hamdan, 2016) merupakan modal penting menuju pengembangan ekonomi kreatif.

Selanjutnya penelitian Simatupang dkk 2008, memberikan kesimpulan bahwa dalam ekonomi kreatif, pemerintah (regulator) dan perusahaan (operator) memerlukan paradgima tersendiri dalam penentuan kebijakan dan manajemen dan terdapat kesamaan pandangan dari para key informan untuk menjadikan Kota Bandung sebagai Kota Kreatif. Kemudian penelitian yang dilakukan Romarina 2016 :35-52, memberikan gambaran pengembangan ekonomi kreatif merupakan pilihan tepat untuk menjaga ketahanan ekonomi dalam kondisi krisis global, momentum globalisasi dan pasar bebas hendaknya memberikan kesempatan yang baik bagi ekonomi kreatif namun jika tidak dikelola dengan baik akan menjadi resiko bagi pihak yang tidak mempersiapkan kompetensinya secara maksimal. Dalam perspektif penelitian ekonomi kreatif, Irawan 2015 memberikan kesimpulan dalam 
penelitiannya bahwa ekonomi kreatif dapat menjadi sebuah jawaban atas tantangan dalam mensejahterakan masyarakat selain itu juga ekonomi kreatif dapat menurunkan tingkat pengangguran. Ekonomi kreatif akan memberikan nilai tambah baik kepada proses produksi maupun kepada sumber daya manusianya sehingga Sistem ekonomi kreatif diyakini akan menjawab tantangan dari berbagai permasalahan yang ada sekarang ini serta akan menggeser sistem yang ada seperti ekonomi komunikasi, ekonomi pertanian, ekonomi industri dan lain-lain.

\section{Metode Penelitian}

Penelitian ini bersifat Policy Oriented dengan menggunakan pendekatan penelitian kebijakan yaitu penelitian yang berfokus pada identifikasi masalah-masalah kebijakan dan pemberian rekomendasi pragmatis kepada pembuat kebijakan sehingga bersifat prespektif (Kusumanegara, (2010:3). Selain itu disebutkan juga penelitian kebijakan adalah penelitian yang diadopsi untuk melengkapi penelitian akademik dan memiliki implikasi kebijakan terkait dengan pengembangan kebijakan publik. (Nusa Putra dan Hendarman, 2012;57). Pendekatan yang digunakan dalam penelitian ini adalah kualitatif yang memaparkan dan menganalisis secara deskriptif. Selain itu penelitian ini juga bersifat deskriptif analitis karena penelitian tidak hanya terbatas pada deskripsi mengenai objek kajian akan tetapi juga melakukan analisis bagaimana inovasi model kebijakan ekonomi kreatif.. Teknik yang dilakukan oleh peneliti adalah survei literatur akademis di bidang keilmuan kebijakan publik guna memperoleh konsep-konsep yang relevan dengan kajian ekonomi kreatif. Sedangkan pengumpulan data dilakukan melalui penelusuran berbagai sumber baik dari dokumen pemerintah maupun pemberitaan media massa cetak dan elektronik sebagai data sekunder yang kemudian diolah dan dideskripsikan dalam bentuk narasi sesuai dengan kebutuhan data. Kemudian dilakukan analisis data berdasarkan teori dan konsep kebijakan publik serta selanjutnya dilakukan proses intrepretasi data.

\section{Analisis dan Pembahasan}

Analisis dan pembahasan penelitian ini berorientasi pada identifikasi masalah-masalah kebijakan pemberian rekomendasi pragmatis kepada pembuat kebijakan sehingga bersifat prespektif (Kusumanegara, (2010:3). Identifikasi dan deskripsi potensi ekonomi kreatif di Provinsi Banten akan dianalisis dan selanjutnya akan diuraikan peluang dan tantangan ekonomi kreatif di Provinsi Banten.

\section{Analisis Potensi Ekonomi Kreatif Provinsi Banten berdasarkan Ekspor}

Ekonomi kreatif merupakan salah satu sektor yang menjadi harapan baru bagi perekonomian Indonesia. Berbeda dengan sektor lain yang sangat tergantung pada eksploitasi sumber daya alam, kekuatan ekonomi kreatif lebih bertumpu kepada keunggulan sumber daya manusia. Karya seni, arsitektur, buku, inovasi teknologi, dan animasi, berasal dari ide-ide kreatif pemikiran manusia. Pengembangan ekonomi kreatif tentunya membutuhkan data-data salah satunya adalah data ekspor ekonomi kreatif. Dan di bawah ini akan diuraikan perkembangan ekspor Provinsi Banten. Perbandingan dengan provinsi lain bertujuan untuk menilai sejauhmana Provinsi Banten dapat berkompetisi dengan Provinsi lain di Indonesia. Menurut Peraturan Presiden Republik Indonesia Nomor 72 Tahun 2015, kegiatan ekonomi kreatif mencakup 16 subsektor. Subsektor-subsektor tersebut adalah: arsitektur; desain interior; desain komunikasi visual; desain produk; film, animasi dan video; fotografi; kriya; kuliner; musik; fashion; aplikasi dan game developer; penerbitan; periklanan; televisi dan radio; seni pertunjukan; dan seni rupa. Masingmasing subsektor tersebut terdiri dari beberapa kelompok Klasifikasi Baku Lapangan Usaha Indonesia (KBLI) 2015 lima digit.

a) Nilai FOB, Peranan dan perubahan Ekspor Ekonomi Kreatif menurut Provinsi Asal (2012-2015).

\begin{tabular}{|c|c|c|c|c|c|c|c|}
\hline \multirow[b]{2}{*}{ No } & \multirow[b]{2}{*}{ Provinsi } & \multicolumn{6}{|c|}{ Nilai FOB (Juta US) } \\
\hline & & 2012 & 2013 & 2014 & 2015 & $\begin{array}{c}\text { Peran } \\
\text { thpdp } \\
\text { eskpor } \\
2015(\%)\end{array}$ & $\begin{array}{l}\text { Persentase perubahan } \\
2015 \text { thdp } 2014\end{array}$ \\
\hline$(1)$ & $(2)$ & (3) & (4) & $(5)$ & $(6)$ & $(7)$ & $(8)$ \\
\hline 1 & Jawa Barat & 5877,6 & 6297,7 & 6559,1 & 6499,2 & 33,56 & $-0,91$ \\
\hline 2 & Jawa Timur & 1401,4 & 1444,3 & 3237,7 & 4037,4 & 20,85 & 24,70 \\
\hline 3 & Banten & 3073,7 & 3047,7 & 2921,7 & 3033,2 & 15,66 & 3,81 \\
\hline
\end{tabular}

Sumber : Laporan Penyusunan Ekspor Ekonomi Kreatif 2010-2015, BPS-Bekraf 
Dalam tabel tersebut terlihat bahwa pada tahun 2012 sampai dengan tahun 2015, perkembangan ekspor ekonomi kreatif Provinsi Banten cenderung stabil dan merupakan provinsi yang mampu melakukan ekspor ekraf secara signifikan. Provinsi asal utama ekspor ekraf adalah Provinsi Jawa Barat dengan nilai ekspor sebesar US $\$ 6,50$ miliar atau 33,56 persen dari keseluruhan ekspor ekraf Indonesia. Provinsi asal ekspor ekraf terbesar kedua setelah Jawa Barat adalah Jawa Timur. Pada tahun 2015 ekspor ekraf dari provinsi ini mencapai nilai sebesar US $\$ 4,04$ miliar atau 20,85 persen dari keseluruhan ekspor ekraf Indonesia. Sedangkan Provinsi Banten menempati urutan ke tiga. Seperti Jawa Timur, Provinsi Banten juga mengalami peningkatan nilai ekspor ekraf pada tahun 2015, yaitu sebesar 3,81 persen. Nilai ekspor ekraf Banten pada tahun 2015 mencapai US $\$ 3,03$ miliar atau 15,66 persen terhadap keseluruhan ekspor ekraf Indonesia.

b) Nilai FOB Ekspor Ekonomi Kreatif Subsektor Kriya menurut Provinsi Asal (2010-2015)

\begin{tabular}{|c|c|c|c|c|c|c|c|}
\hline \multirow{2}{*}{ Provinsi Asal } & \multicolumn{6}{|c|}{ Nilai FOB (Juta US\$) } & \multirow{2}{*}{$\begin{array}{c}\% \\
\text { Perubahan '15 thd ' } 14\end{array}$} \\
\hline & 2010 & 2011 & 2012 & 2013 & 2014 & 2015 & \\
\hline (1) & (2) & (3) & (4) & (5) & (6) & (7) & $(8)$ \\
\hline JawaTimur & 992,1 & 1091,1 & 1054,6 & 1077,2 & 2808,1 & 3575,4 & 27,33 \\
\hline Jawa Barat & 1277,5 & 1352,4 & 1425,0 & 1374,7 & 1384,9 & 1333,4 & $-3,72$ \\
\hline Jawa Tengah & 868,0 & 769,4 & 700,1 & 694,5 & 777,1 & 800,1 & 2,95 \\
\hline DKI Jakarta & 343,9 & 378,7 & 387,9 & 349,6 & 542,1 & 787,5 & 45,26 \\
\hline Banten & 309,4 & 343,7 & 340,7 & 325,2 & 314,1 & 340,5 & 8,38 \\
\hline
\end{tabular}

Sumber : Laporan Penyusunan Ekspor Ekonomi Kreatif 2010-2015, BPS-Bekraf

Berdasarkan tabel tersebut diketahui bahwa pada tahun 2015 ekspor subsektor kriya menurut provinsi asal didominasi oleh ekspor dari Pulau Jawa dan sekitarnya. Nilai ekspor tertinggi berasal dari provinsi Jawa Timur yang mencapai US\$3.575,4 juta, dengan kenaikan sebesar 27,33 persen dibandingkan pada tahun 2014. Kemudian diikuti oleh provinsi Jawa Barat sebesar US\$1.333,4 juta. Namun bila dibandingkan dengan tahun 2014, ekspor subsektor kriya yang berasal dari provinsi Jawa Barat mengalami penurunan sebesar 3,72 persen. Untuk provinsi Jawa Tengah mengalami peningkatan kinerja yang positif sebesar 2,95 persen dengan nilai US\$800,1 juta. Provinsi Banten mengalami peningkatan masing-masing sebesar 45,26 persen dan 8,38 persen serta cenderung mengalami perkembangan ekspor yang fluktuatif. Akan tetapi secara keseluruhan menunjukan perkembangan yang positif.

c) Nilai FOB Ekspor Ekonomi Kreatif Subsektor Kuliner menurut Provinsi asal (20102015)

\begin{tabular}{|l|c|c|c|c|c|c|c|}
\hline & $\mathbf{2 0 1 0}$ & $\mathbf{2 0 1 1}$ & $\mathbf{2 0 1 2}$ & $\mathbf{2 0 1 3}$ & $\mathbf{2 0 1 4}$ & $\mathbf{2 0 1 5}$ & '15 thd '14 \\
\hline \multicolumn{1}{|c|}{$(\mathbf{1})$} & $\mathbf{( 2 )}$ & $\mathbf{( 3 )}$ & $\mathbf{( 4 )}$ & $\mathbf{( 5 )}$ & $\mathbf{( 6 )}$ & $\mathbf{( 7 )}$ & $\mathbf{( 8 )}$ \\
\hline Jawa Barat & 287,2 & 382,6 & 397,7 & 420,3 & 480,7 & 529,8 & 10,22 \\
\hline DKI Jakarta & 93,4 & 126,3 & 137,2 & 144,6 & 141,9 & 151,8 & 6,99 \\
\hline Jawa Timur & 53,9 & 74,3 & 84,2 & 83,8 & 120,6 & 147,2 & 22,05 \\
\hline Kepulauan Riau & 0,7 & 72,3 & 7,6 & 33,2 & 32,9 & 91,6 & 178,01 \\
\hline Riau & 1,7 & 15,4 & 155,1 & 99,1 & 112,5 & 86,7 & $-22,90$ \\
\hline Banten & $\mathbf{5 0 , 8}$ & $\mathbf{8 3 , 9}$ & $\mathbf{8 0 , 8}$ & $\mathbf{7 3 , 4}$ & $\mathbf{7 6 , 3}$ & $\mathbf{7 8 , 9}$ & $\mathbf{3 , 3 3}$ \\
\hline
\end{tabular}

Sumber : Laporan Penyusunan Ekspor Ekonomi Kreatif 2010-2015, BPS-Bekraf

Pada tahun 2015, Jawa Barat merupakan provinsi asal ekspor subsektor kuliner Indonesia terbesar dengan nilai US\$529,8 juta atau peranannya mencapai 44,94 persen terhadap nasional. Provinsi asal ekspor terbesar kedua adalah DKI Jakarta, ketiga adalah Jawa Timur, keempat adalah Kepulauan Riau, dan kelima adalah Riau masing-masing mencapai US\$151,8 juta; US\$147,2 juta; US\$91,6 juta; dan US\$86,7 juta. Provinsi Banten mengalami tingkat perkembangan yang cukup signifikan dari kurun waktu tahun 2010 sampai dengan 2012, walaupun 
terjadi penurunan pada tahun 2013, akan tetapi mengalami kenaikan pada tahun 2014 dan tahun 2015. Pertumbuhan dari tahun 2015 ke tahun
2014 adalah sebesar 3.33 persen. Sedangkan dari berat bersihnya, ekspor kuliner dapat dilihat pada tabel berikut ini :

\begin{tabular}{|l|c|c|c|c|c|c|c|}
\hline \multicolumn{1}{|c|}{ Nama Provinsi } & $\mathbf{2 0 1 0}$ & $\mathbf{2 0 1 1}$ & $\mathbf{2 0 1 2}$ & $\mathbf{2 0 1 3}$ & $\mathbf{2 0 1 4}$ & $\mathbf{2 0 1 5}$ & '15 thd '14 \\
\hline \multicolumn{1}{|c|}{$(\mathbf{1})$} & $\mathbf{( 2 )}$ & $\mathbf{( 3 )}$ & $\mathbf{( 4 )}$ & $\mathbf{( 5 )}$ & $\mathbf{( 6 )}$ & $\mathbf{( 7 )}$ & $\mathbf{( 8 )}$ \\
\hline Jawa Barat & 113,5 & 139,4 & 138,2 & 140,8 & 157,4 & 182,0 & 15,66 \\
\hline DKI Jakarta & 32,2 & 41,6 & 38,0 & 36,9 & 35,6 & 34,8 & $-2,23$ \\
\hline Jawa Timur & 31,0 & 37,1 & 37,7 & 43,1 & 62,6 & 71,5 & 14,22 \\
\hline Kepulauan Riau & 0,3 & 18,5 & 2,1 & 11,4 & 16,7 & 43,7 & 161,96 \\
\hline Riau & 0,9 & 4,3 & 61,3 & 56,0 & 66,9 & 55,6 & $-16,92$ \\
\hline Banten & $\mathbf{2 0 , 2}$ & $\mathbf{2 4 , 8}$ & $\mathbf{2 3 , 4}$ & $\mathbf{2 3 , 5}$ & $\mathbf{2 7 , 1}$ & $\mathbf{3 0 , 2}$ & $\mathbf{1 1 , 5 5}$ \\
\hline
\end{tabular}

Sumber : Laporan Penyusunan Ekspor Ekonomi Kreatif 2010-2015, BPS-Bekraf

Berdasarkan tabel tersebut dapat dlihat bahwa provinsi asal ekspor subsektor kuliner terbesar selama enam tahun terakhir ini adalah Jawa Barat. Pada tahun 2015 berat bersih ekspornya mencapai 182,0 ribu ton, atau meningkat sebesar 15,66 persen jika dibandingkan tahun 2014. Peranannya mencapai
39,14 persen terhadap nasional. Banten merupakan provinsi yang dalam kuruun waktu enam tahun terakhir mengalami peningkatan. Pada tahun2015 dengan berat bersih mencapai 30.2 ribu ton atau meningkat 11.55 persen dibandingkan tahun 2014.

d) Nilai FOB Ekspor Ekonomi Kreatif Subsektor Fashion menurut Provinsi asal (20102015)

\begin{tabular}{|l|c|c|c|c|c|c|}
\hline \multirow{2}{*}{$\begin{array}{c}\text { Provinsi Asal } \\
\text { Barang }\end{array}$} & \multicolumn{7}{c|}{ Nilai FOB (Juta US\$) } \\
\cline { 2 - 8 } & $\mathbf{2 0 1 0}$ & $\mathbf{2 0 1 1}$ & $\mathbf{2 0 1 2}$ & $\mathbf{2 0 1 3}$ & $\mathbf{2 0 1 4}$ & $\mathbf{2 0 1 5}$ \\
\hline (1) & $\mathbf{( 2 )}$ & $\mathbf{( 3 )}$ & $\mathbf{( 4 )}$ & $\mathbf{( 5 )}$ & $\mathbf{( 6 )}$ & $\mathbf{( 7 )}$ \\
\hline Jawa Barat & 3339,0 & 4083,1 & 4041,7 & 4483,7 & 4686,6 & 4632,2 \\
\hline Janten & $\mathbf{2 1 9 7 , 8}$ & $\mathbf{2 7 3 8 , 0}$ & $\mathbf{2 ~ 6 5 1 , 6}$ & $\mathbf{2 ~ 6 4 8 , 1}$ & $\mathbf{2 ~ 5 3 0 , 0}$ & $\mathbf{2 ~ 6 1 2 , 5}$ \\
\hline Dawa Tengah & 1061,1 & 1248,4 & 1302,0 & 1478,4 & 1578,6 & 1836,4 \\
\hline Jawa Timurta & 1447,9 & 1613,1 & 1405,8 & 1264,3 & 1205,1 & 1086,6 \\
\hline Provinsi Lainnya & 181,2 & 237,1 & 260,2 & 281,3 & 307,1 & 310,7 \\
\hline Total Subsektor Fashion & 357,4 & 437,1 & 423,1 & 437,4 & 391,4 & 416,8 \\
\hline
\end{tabular}

Sumber : Laporan Penyusunan Ekspor Ekonomi Kreatif 2010-2015, BPS-Bekraf

Bila dikaji dari provinsi asal barang, ekspor subsektor fashion lebih banyak di produksi di provinsi Jawa Barat, Banten, Jawa Tengah, dan DKI Jakarta. Peran ekspor keempat provinsi tersebut terhadap total ekspor subsektor fashion di tahun 2015 adalah 42,52 persen, 23,98 persen, 16,85 persen, dan 9,97 persen. Dari provinsi Banten pada tahun 2010 diekspor dengan nilai US\$2.197,8 juta, berat bersih 131,7 ribu ton dan menjadi US $\$ 2.612,5$ juta berat bersih 135,3 ribu ton. Provinsi asal barang lainnya adalah Jawa
Tengah dimana nilai ekspor subsektor fashion di tahun 2010 mencapai nilai US\$1.061,1 juta dengan berat bersih 73,6 ribu ton, sedangkan di tahun 2015 nilainya mencapai US $\$ 1.836,4$ juta dengan berat bersih 94,1 ribu ton.

Ekspor subsektor fashion juga banyak diproduksi di provinsi DKI Jakarta yang pada tahun 2010 nilainya mencapai US $\$ 1.447,9$ juta, berat bersih 103,4 ribu ton, sementara nilainya mengalami penurunan hingga menjadi US $\$ 1.086,4$ juta, berat bersih 88,5 ribu ton. 
e) Nilai FOB Ekspor Ekonomi Kreatif Subsektor Penerbitan menurut Provinsi asal (20102015)

\begin{tabular}{|c|c|c|c|c|c|c|c|}
\hline \multirow{2}{*}{ Provinsi } & \multicolumn{6}{|c|}{ Nilai FOB (Ribu US\$) } & \multirow{2}{*}{$\frac{\% \text { Perubahan }}{2015 \text { thd } 2014}$} \\
\hline & 2010 & 2011 & 2012 & 2013 & 2014 & 2015 & \\
\hline 1) & (2) & (3) & (4) & (5) & (6) & (7) & $(8)$ \\
\hline Jawa Tengah & 3175,8 & 2937,2 & 2399,4 & 2660,5 & 2907,5 & 6608,2 & 127,28 \\
\hline DKI Jakarta & 9584,6 & 5620,4 & 6286,3 & 8547,5 & 4735,6 & 6286,3 & 32,74 \\
\hline Jawa Timur & 1892,5 & 989,0 & 2251,6 & 1945,0 & 1832,8 & 3987,4 & 117,56 \\
\hline Jawa Barat & 12195,4 & 10686,0 & 9173,9 & 12155,7 & 4844,3 & 3741,0 & $-22,78$ \\
\hline Banten & 1132,6 & 1465,5 & 544,8 & 971,6 & 1133,8 & 1347,6 & 18,86 \\
\hline
\end{tabular}

Sumber : Laporan Penyusunan Ekspor Ekonomi Kreatif 2010-2015, BPS-Bekraf

Provinsi asal utama ekspor subsektor penerbitan tahun 2015 antara lain Jawa Tengah, DKI Jakarta, Jawa Timur, Jawa Barat, Banten, Bali, Kepulauan Riau, Kalimantan Timur, DI Yogyakarta dan Lampung. Pada tahun 2014 provinsi asal yang memiliki kontribusi terbesar terhadap ekspor subsektor penerbitan adalah Jawa Barat sebesar 30,31 persen. Pada tahun 2015 kontribusi ekspor terbesar berasal dari Jawa tengah yaitu 29,59 persen sedangkan kontribusi Jawa Barat turun menjadi 16,75 persen. Ekspor dari provinsi Jawa Tengah mencapai nilai US $\$ 6.608,2$ ribu pada tahun 2015, nilai ini mengalami peningkatan sebesar 127,28 persen dibandingkan dengan ekspor tahun 2014. Menurut kelompok KBLI, ekspor subsektor penerbitan yang berasal dari Jawa Tengah sebagian besar merupakan kelompok penerbitan buku (KBLI 58110) yaitu sebesar US $\$ 2.785,0$ ribu pada tahun 2015.

Provinsi asal terbesar selanjutnya adalah Jawa Timur yang mencapai US\$3.987,4 ribu pada tahun 2015. Pada periode 2010 hingga 2015 ekspor dari provinsi ini memiliki kecenderungan meningkat dengan kelompok utama yaitu industri percetakan umum (KBLI 18111) yang mencapai US\$3.690,2 ribu pada 2015. Sama dengan tren provinsi DKI Jakarta, ekspor subsektor penerbitan yang berasal dari provinsi Jawa Barat juga mengalami penurunan dalam kurun waktu 2010 hingga 2015. Pada tahun 2010 hampir 42,64 persen ekspor berasal dari provinsi Jawa Barat, nilai kontribusi ini semakin menurun hingga mencapai 16,75 persen pada tahun 2015. Dari nilai ekspor sebesar US\$3.741,0 ribu pada tahun 2015, ekspor dari provinsi Jawa Barat sebagian besar merupakan kelompok aktivitas penerbitan lainnya (KBLI 58190) senilai US\$3.476,0 ribu. Berbeda dengan Jawa Barat, ekspor subsektor penerbitan dari Banten menunjukkan tren yang datar dari tahun 2010 hingga 2015. Pada tahun 2014 ekspor dari provinsi Banten memiliki kontribusi sebesar 7,09 persen terhadap total ekspor subsektor penerbitan. Pada tahun 2015 nilai kontribusi tersebut kemudian turun menjadi 6,03 persen meskipun nilainya meningkat menjadi US\$1.347,6 ribu. Kelompok utama dari provinsi ini merupakan aktivitas penerbitan lainnya (KBLI 58190) senilai US\$1.049,6 ribu pada tahun 2015.

f) Nilai FOB Ekspor Ekonomi Kreatif Subsektor Seni Rupa menurut Provinsi asal (20102015)

\begin{tabular}{|l|c|c|c|c|c|c|c|c|}
\hline Provinsi Asal Barang & $\mathbf{2 0 1 0}$ & $\mathbf{2 0 1 1}$ & $\mathbf{2 0 1 2}$ & $\mathbf{2 0 1 3}$ & $\mathbf{2 0 1 4}$ & $\mathbf{2 0 1 5}$ & $\mathbf{2 0 1 4}$ thd 2013 & $\mathbf{2 0 1 5}$ thd 2014 \\
\hline \multicolumn{1}{|c}{$\mathbf{1})$} & $\mathbf{( 2 )}$ & $\mathbf{( 3 )}$ & $\mathbf{( 4 )}$ & $\mathbf{( 5 )}$ & $\mathbf{( 6 )}$ & $\mathbf{( 7 )}$ & $\mathbf{( 8 )}$ & $\mathbf{( 9 )}$ \\
\hline Bali & 2732,4 & 2957,5 & 2006,6 & 1595,4 & 1437,3 & 1547,9 & $-9,91$ & 7,70 \\
\hline DKI Jakarta & 845,0 & 1530,8 & 6957,6 & 857,6 & 1096,3 & 837,6 & 27,82 & $-23,60$ \\
\hline DI Yogyakarta & 382,0 & 106,7 & 312,6 & 533,7 & 364,6 & 284,8 & $-31,68$ & $-21,89$ \\
\hline Jawa Tengah & 261,9 & 1222,0 & 1010,2 & 662,7 & 402,6 & 191,4 & $-39,24$ & $-52,46$ \\
\hline Jawa Timur & 201,7 & 50,0 & 111,8 & 47,3 & 97,3 & 149,5 & 105,60 & 53,66 \\
\hline Jawa Barat & 944,1 & 2907,9 & 4063,3 & 6832,4 & 2016,8 & 17,6 & $-70,48$ & $-99,13$ \\
\hline
\end{tabular}




\begin{tabular}{|l|c|c|c|c|c|c|c|c|}
\hline Nusa Tenggara & 0,0 & 0,0 & 0,5 & 1,4 & 4,0 & 3,3 & 195,96 & $-18,57$ \\
\hline Banten & $\mathbf{2 5 9 , 6}$ & $\mathbf{1 6 6 , 3}$ & $\mathbf{9 7 , 6}$ & $\mathbf{2 4 , 6}$ & $\mathbf{1 2 8 , 6}$ & $\mathbf{2 , 6}$ & $\mathbf{4 2 2 , 0 9}$ & $\mathbf{- 9 7 , 9 4}$ \\
\hline Total Ekspor & 5631,9 & 8943,7 & 14573,6 & 10556,6 & 5550,6 & 3035,7 & $-47,42$ & $-45,31$ \\
\hline
\end{tabular}

Sumber : Laporan Penyusunan Ekspor Ekonomi Kreatif 2010-2015, BPS-Bekraf

Provinsi asal utama ekspor subsektor seni rupa tahun 2015 antara lain Bali, DKI Jakarta, DI Yogyakarta, Jawa Tengah, Jawa Timur, Jawa Barat. Pada tahun 2015 Provinsi Bali berkontribusi mengekspor subsektor seni rupa sebesar 50,99 persen dengan nilai sebesar US $\$ 1.547,9$ ribu, atau naik sebesar 7,70 persen dibandingkan dengan ekspor tahun 2014. Komoditi ekspor asal barang provinsi Bali tahun 2015 yang terbesar adalah lukisan, gambar dan gambar pastel yaitu sebesar US\$1.380,3 ribu disusul arca dan patung asli, selain dari logam, batu, plastik, kayu dan tanah liat dengan nilai US\$167,6 juta. Provinsi DKI Jakarta tahun 2015 menduduki posisi kedua dengan kontribusi pada subsektor seni rupa sebesar 27,59 persen dengan nilai sebesar US $\$ 837,6$ ribu, atau turun sebesar 23,60 persen dibandingkan dengan ekspor tahun 2014. Komoditi ekspor asal barang provinsi DKI
Jakarta tahun 2015 yang terbesar adalah lukisan, gambar dan gambar pastel yaitu sebesar US\$770,8 ribu disusul arca dan patung asli, selain dari logam, batu plastik, kayu dan tanah liat dengan nilai US\$66,8 juta.

Sama seperti halnya DKI Jakarta, Provinsi asal barang DI Yogyakarta tahun 2015 mengalami perubahan negatif sebesar 21,89 persen dari US $\$ 364,6$ ribu menjadi US $\$ 284,8$ ribu, dengan komoditi yang terbesar diekspor adalah lukisan, gambar dan gambar pastel yaitu sebesar US\$274,0 ribu disusul arca dan patung asli, selain dari logam, batu, plastik, kayu dan tanah liat dengan nilai US $\$ 10,8$ ribu. Kontribusi dari ketiga provinsi asal barang tersebut terhadap total ekspor subsektor seni rupa tahun 2015 sebesar 87,96 persen, meningkat dibandingkan dengan tahun 2014 yang berkontribusi sebesar 52,21 persen

g) Persentase Ekonomi Kreatif Provinsi Banten berdasarkan jenis kelamin

\begin{tabular}{|c|c|c|c|}
\hline \multirow{2}{*}{ Provinsi } & \multicolumn{2}{|c|}{ Jenis Kelamin } & Total \\
\cline { 2 - 4 } & Laki-laki & Perempuan & \\
\hline Banten & 84,71 & 15,29 & 100,00 \\
\hline
\end{tabular}

Sumber : Profil Usaha Ekonomi Kreatif, BPS-Bekraf, 2015.

Berdasarkan tabel di atas dapat dilihat bahwa jenis kelamin laki-laki sebesar 84.71 merupakan faktor terbesar penyumbang ekonomi kreatif di Provinsi Banten. Hal ini menunjukkan bahwa jenis kelamin laki-laki lebih banyak mendapatkan kesempatan untuk melakukan aktivitas pada sektor ekonomi kreatif dan belum meratanya kesempatan bagi perempuan untuk mendapatkan akses pada ekonomi kreatif

\section{h) Persentase Usaha Ekonomi Kreatif berdasarkan Status Badan Usaha, 2016}

\begin{tabular}{|c|c|c|c|c|c|c|c|}
\hline \multirow{2}{*}{ Provinsi } & \multicolumn{7}{|c|}{ Status Badan Usaha (persentase) } \\
\cline { 2 - 8 } & $\begin{array}{c}\text { PT/PT } \\
\text { Persero/ } \\
\text { Perum }\end{array}$ & $\mathbf{C V}$ & Firma & $\begin{array}{c}\text { Koperasi// } \\
\text { Dana } \\
\text { Pensiun }\end{array}$ & Yayasan & $\begin{array}{c}\text { Izin } \\
\text { Khusus }\end{array}$ & $\begin{array}{c}\text { Tidak } \\
\text { Berbadan } \\
\text { Usaha }\end{array}$ \\
\hline (1) & $\mathbf{( 2 )}$ & $\mathbf{( 3 )}$ & $\mathbf{( 4 )}$ & $\mathbf{( 5 )}$ & $\mathbf{( 6 )}$ & $\mathbf{( 7 )}$ & $\mathbf{( 8 )}$ \\
\hline DKI Jakarta & 32,28 & 8,35 & 0,37 & - & 2,41 & 3,90 & 52,69 \\
\hline Jawa Barat & 14,80 & 9,80 & 0,53 & - & 2,14 & 10,16 & 62,57 \\
\hline Jawa Tengah & 12,55 & 11,09 & 0,18 & - & 1,09 & 13,45 & 61,64 \\
\hline DI Yogyakarta & 30,53 & 14,21 & 1,05 & - & 1,58 & 3,68 & 48,95 \\
\hline Jawa Timur & 13,54 & 10,15 & 0,34 & 0,34 & 0,68 & 14,04 & 60,91 \\
\hline Banten & $\mathbf{1 8 , 1 8}$ & $\mathbf{8 , 2 6}$ & $\mathbf{2 , 0 7}$ & $\mathbf{0 , 4 1}$ & $\mathbf{2 , 8 9}$ & $\mathbf{9 , 0 9}$ & $\mathbf{5 9 , 0 9}$ \\
\hline
\end{tabular}

Sumber : Profil Usaha Ekonomi Kreatif, BPS-Bekraf, 2015. 
Berdasarkan tabe di atas dapat dilihat bahwa status badan usaha ekonomi kreatif Provinsi Banten masih didominasi oleh status badan usaha yang tidak berbadan usaha dengan persentase sebesar 59.09, diikuti dengan PT/Persero/Perum dengan persentase sebesar 18.18 persen, izin khusus sebesar 9.08 dengan persentase 9.09 dan CV sebesar 8.26. Hal ini menunjukkan bahwa perlu adanya upaya-upaya kelembagaan dalam mendukung ekonomi kreatif dengan memberikan status badan usaha terhadap usaha ekonomi kreatif sekaligus mendorong badan usaha seperti CV, Firma, koperasi dan yayasan untuk dapat berkembang dan memperoleh status badan usaha ekonomi kreatif.

i) Persentase Usaha Ekonomi Kreatif berdasarkan Status Penanaman Modal

\begin{tabular}{|l|c|c|c|c|}
\hline \multirow{2}{*}{\multicolumn{1}{c|}{ Provinsi }} & \multicolumn{3}{c|}{ Status Penanaman Modal } & \multirow{2}{*}{ Total } \\
\cline { 2 - 4 } \multicolumn{1}{|c|}{$(1)$} & PMA & PMDN & Lainnya & $(5)$ \\
\hline DKI Jakarta & $(2)$ & $(3)$ & $(4)$ & 100,00 \\
\hline Jawa Barat & 0,74 & 23,93 & 75,32 & 100,00 \\
\hline Jawa Tengah & 0,89 & 11,05 & 88,06 & 100,00 \\
\hline DI Yogyakarta & 0,18 & 12,55 & 87,27 & 100,00 \\
\hline Jawa Timur & 2,11 & 18,95 & 78,95 & 100,00 \\
\hline Banten & 0,17 & 10,83 & 89,00 & $\mathbf{1 0 0 , 0 0}$ \\
\hline
\end{tabular}

Sumber : Profil Usaha Ekonomi Kreatif, BPS-Bekraf, 2015.

Berdasarkan tabel di atas dapat dilihat bahwa status penanaman modal di Provinsi Banten didominasi oleh status kepemilikan penanaman modal bukan PMA dan PMDN sebesar 91.32. Status penanaman modal tersebut merupakan penanaman modal pribadi dan swasta melalui berbagai kepemilikan usaha pribadi dan bersama.

\section{j) Persentase ekonomi kreatif berdasarkan Sumber dana}

\begin{tabular}{|c|c|c|c|c|c|c|}
\hline \multirow{2}{*}{ Provinsi } & \multicolumn{6}{|c|}{ Sumber Dana } \\
\cline { 2 - 7 } & \multicolumn{2}{|c|}{ Pinjaman Bank } & \multicolumn{2}{c|}{ Pinjaman Pribadi } & \multicolumn{2}{c|}{ Ventura Capital } \\
\hline \multirow{2}{*}{ Banten } & Ya & Tidak & Ya & Tidak & Ya & Tidak \\
\cline { 2 - 7 } & 19.25 & 80.75 & 11.30 & 88.70 & 0.84 & 99.16 \\
\hline
\end{tabular}

Sumber : Profil Usaha Ekonomi Kreatif, BPS-Bekraf, 2015.

Berdasarkan tabel di atas dapat dilihat bahwa persentase ekonomi kreatif berdasarkan sumber dana pinjaman bank sebesar 19.25, pinjaman pribadi 11.30 dan ventura capital 0.84 . Hal ini menunjukkan bahwa perlu ada peningkatan sumber dana dari ketiga sumber dana tersebut agar perkembangan ekonomi kreatif di Banten dapat berjalan lebih optimal.

\section{Peluang dan Tantangan Ekonomi Kreatif Provinsi Banten \\ Dapat diuraikan peluang dan tangan} ekonomi kreatif di Provinsi Banten yang dapat menjadi modal pengembangan kebijakan ekonomi kreatif yaitu sebagai berikut :

a. Perkembangan ekonomi Kreatif Provinsi Banten cukup menjanjikan, indikator utama dari ekspor menunjukkan bahwa peran ekraf terhadap ekspor Provinsi Banten sebesar $15,66 \%$ (ketiga seluruh Indonesia) b. Posisi Geostrategis Banten yang berada di ujung barat pulau jawa memposisikan Banten sebagai pintu gerbang pulau Jawa dan Sumatera dan berbatasan langsung dengan Ibukota Negara RI dapat menjadi pendorong pengembangan ekonomi kreatif.

c. Terdapat potensi sumberdaya manusia pendukung pengembangan ekonomi kreatif, terutama kelompok penduduk usia muda (kelompok umur $19-40$ tahun) yang cukup banyak dan berpendidikan tinggi yang dapat menjadi sumberdaya manusia bagi pengembangan ekonomi kreatif.

d. Tersedianya fasilitas website pemerintah Provinsi Banten dan web resmi setiap kabupaten/kota di Provinsi Banten dan SKPD Dinas Perindustrian Perdagangan, Koperasi di tiap Kabupaten/kota sebagai wadah promosi potensi ekonomi kreatif Provinsi Banten. 
e. Terdapat beberapa perguruan tinggi (Universitas Tirtayasa, Universitas Serang Raya, IAIN dan STIE Bina Bangsa) yang dapat mendukung bagi pengembangan produk Ilmu Pengetahuan teknologi kreatif di Provinsi Banten.

f. Di Provinsi Banten terdapat beberapa sarana, jalur jalan dan gedung pertemuan umum yang dapat dioptimalkan fungsinya menjadi pusat aktivitas ekonomi kreatif Provinsi Banten, sebagaimana kota-kota lain, misalnya : wisata belanja, wisata kuliner, pusat aktivitas/kegiatan kaum muda dan lain-lain.

g. Di Provinsi Banten terdapat beberapa event atau kegiatan masyarakat yang dapat menjadi media atau forum bagi pengembangan ekonomi kreatif, antara lain: Moment Hari Jadi Provinsi Banten, hari-hari besar nasional, Festival Budaya dan lain-lain. Kegiatan tersebut dapat dipromosikan dalam penguatan grand image Provinsi Banten sebagai Provinsi Ekonomi Kreatif.

\section{Sedangkan tantangan pengembangan ekonomi kreatif Provinsi Banten adalah :}

a. Belum optimalnya fasilitasi dan kesadaran tentang Hak Kekayaan Intelektual (HAKI) terhadap produk Asli Provinsi Banten.

b. Belum tersedianya basis data 16 sub sektor ekonomi kreatif yang dapat menjadi data dasar bagi SKPD terkait dalam upaya pengembangan ekonomi kreatif di Provinsi Banten.

c. Masih minimnya program dan kegiatan pemerintah daerah yang memfasilitasi penguatan sumberdaya kreatif sebagai basis bagi pengembangan ekonomi kreatif di Provinsi Banten.

d. Belum optimalnya pengembangan sentra dan cluster industri kreatif Provinsi Banten.

e. Belum termanfaatkannya arena, gedung kesenian atau art centre yang representatif dan dapat menjadi pusat aktivitas dan kegiatan pengembangan ekonomi kreatif di Provinsi Banten

f. Masuknya produk-produk kreatif berharga murah dari luar negeri (Jepang, China, Korea dan Taiwan) terutama mainan anakanak, tekstil, garment, software gratis, film, VCD, Komik dan buku cetakan ke pasar tradisional yang mendesak produk kreatif lokal.

g. Masuknya produk kerajinan dan fesyen sejenis dari daerah lain dengan kualitas yang lebih baik, dapat mengancam pasar industri kerajinan dan karya masyarakat Provinsi Banten.

h. Masuknya produk-produk yang memperoleh dukungan perusahaan multi nasional (multinational corporation), seperti $\mathrm{Mc}$ Donald, Giant, Carefour, dan lain-lain.

\section{Inovasi Model Kebijakan Pengembangan Ekonomi Kreatif}

Pendekatan model kebijakan publik yang digunakan dalam penelitian ini adalah model kebijakan publik jaringan. Model ini memahami bahwa proses implementasi kebijakan adalah sebuah complex of interaction processes diantara sejumlah besar aktor yang berada dalam suatu jaringan (network) aktor-aktor yang independent. (Dedi Mulyadi, 2015:82). Dengan demikian aktoraktor ekonomi kreatif saling berinteraksi guna memecahkan permasalahan-permasalahan secara komprehensif dan pengambilan keputusan demi kepentingan berbagai stakeholder yang terlibat dalam pengembangan kebijakan ekonomi kreatif di Provinsi Banten. Oleh sebab itu sebagai sebuah alternatif, inovasi modal kebijakan ekonomi kreatif di Banten yang perlu dikembangkan adalah jejaring kebijakan dengan menekankan pada sinergitas stakeholder. Pentingnya komitmen dan sinergi stakeholder dalam memanfaatkan momentum bagi kemajuan pertumbuhan ekonomi kreatif. Dengan mendorong adanya regulasi tentang pengembangan ekonomi kreatif sebagai payung hukum bagi stakeholder dengan sinergi antar berbagai kementrian dan badan ekonomi kreatif sebagai leading sector.

Berdasarkan pendekatan indikator geografis, potensi Banten sebagai center ekonomi kreatif sangatlah besar, dengan jumlah penduduk, sumber daya alam dan lokasi yang strategis menjadikan Provinsi Banten sebagai provinsi unggulan dalam ekonomi kreatif. Nama besar sejarah Banten dapat menjadi salah satu magnit bagi pengembangan ekonomi kreatif sehingga tidaklah keliru apabila penyematan nama Banten dapat digunakan sebagai trademark. Inovasi model pengembangan kebijakan ekonomi kreatif di Provinsi Banten dikembangkan layaknya bagian dari bangunan masjid Banten Lama dengan filosofis bentuk atap masjid seperti punden berundak dengan atap tumpang lima yang terdiri dari masyarakat/publik selaku faktor pendukung terbesar dalam setiap regulasi yang dikeluarkan oleh Pemerintah Pusat maupun daerah, akademisi/intelektual digambarkan sebagai pusat laboratorium ekonomi kreatif dalam menciptakan produk dan hasil penelitian, dukungan pelaku bisnis/swasta selaku 
penyedia dana, pengguna, distributor dan pemasar hasil-hasil produk ekonomi kreatif serta peran sentral komunitas kreatif sebagai ujung tombak pengembangan ekonomi kreatif di Provinsi Banten.

Sedangkan seperti layaknya pintu masjid Banten lama yang seluruhnya berjumlah enam buah adalah faktor penting dalam mendukung keberlanjutan pengembangan ekonomi kreatif di Provinsi Banten yang terdiri dari Kelembagaan dan Haki, skema pembiayaan/permodalan, sumber daya manusia, infrastruktur dan teknologi, pemasaran/distribusi dan potensi sumber daya alam.

Gambar 1

Inovasi Model Pengembangan

Kebijakan Ekonomi Kreatif Banten

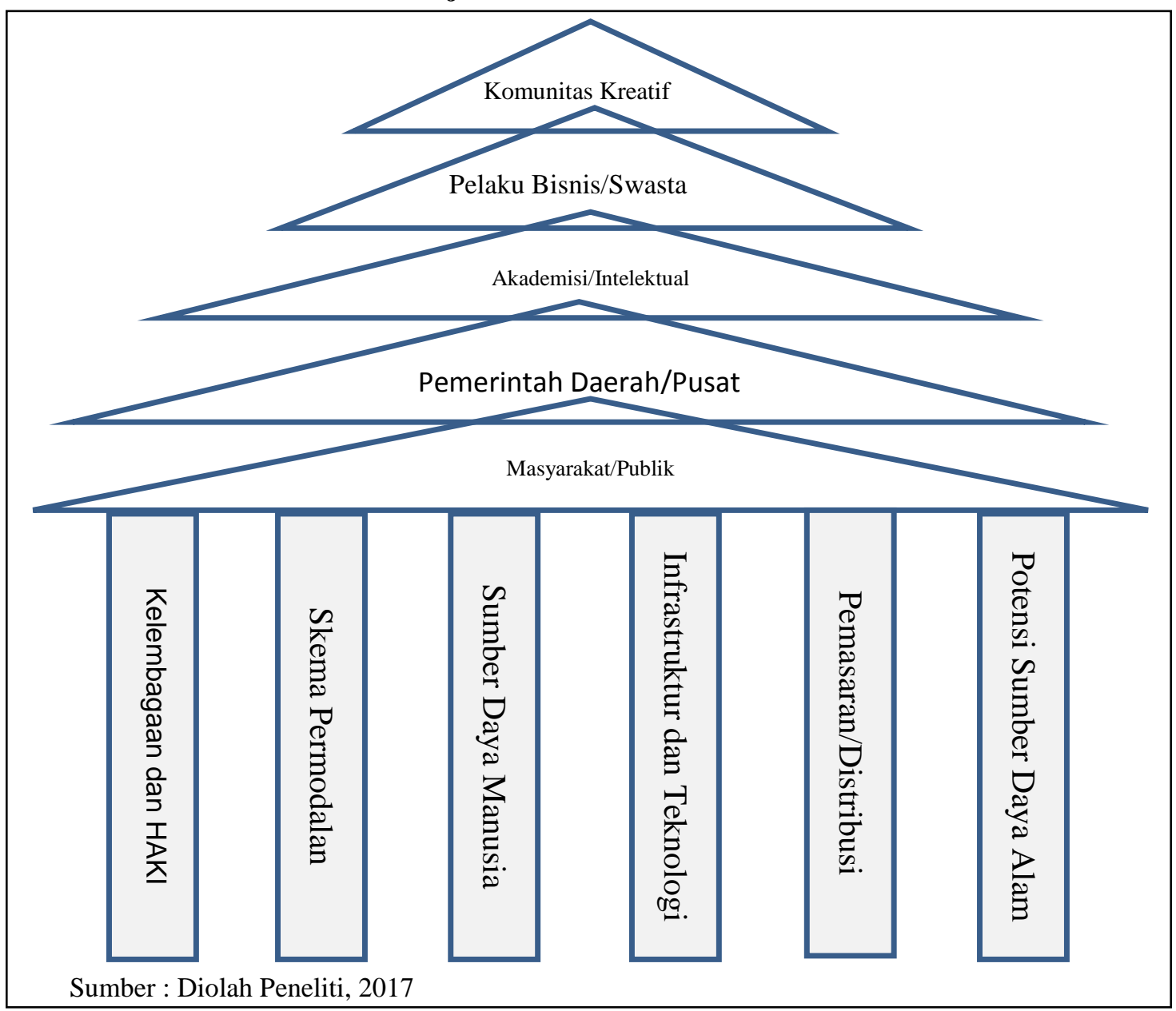

Pemetaan indiaktor potensi geografis dan kekhasan wilayah serta beragamnya produk lokal khususnya yang berpotensi untuk dikembangkan seperti makanan olahan, tenun, dan kerajinan. Potensi wisata Banten dengan beragam destinasi wisata mulai wisata pantai, wisata alam, wisata religi, wisata ziarah, pendidikan, wisata belanja, wisata budaya serta sejarah. Potensi tersebut akan saling mendukung dan berkaitan langsung untuk mengembangkan industri kreatif di Banten. Perspektif geo-ekonomi dan geo-regional yang terintegrasi dengan kondisi demografis menjadi modal Provinsi Banten dalam pengembangan ekonomi kreatif. Masyarakat didorong untuk mengapresiasi setiap produk ekonomi kreatif. Dalam konteks yang ideal, setiap kabupaten/kota di Provinsi Banten menciptakan destinasi kota berbasis ekonomi kreatif berdasarkan spesifikasi dan kekhasan wilayahnya masing-masing. Dengan dukungan aksesibilitas dan konektivitas maka diharapkan dapat terjadi multiplier effect bagi pertumbuhan perekonomian kota dan kabupaten di Provinsi Banten. 


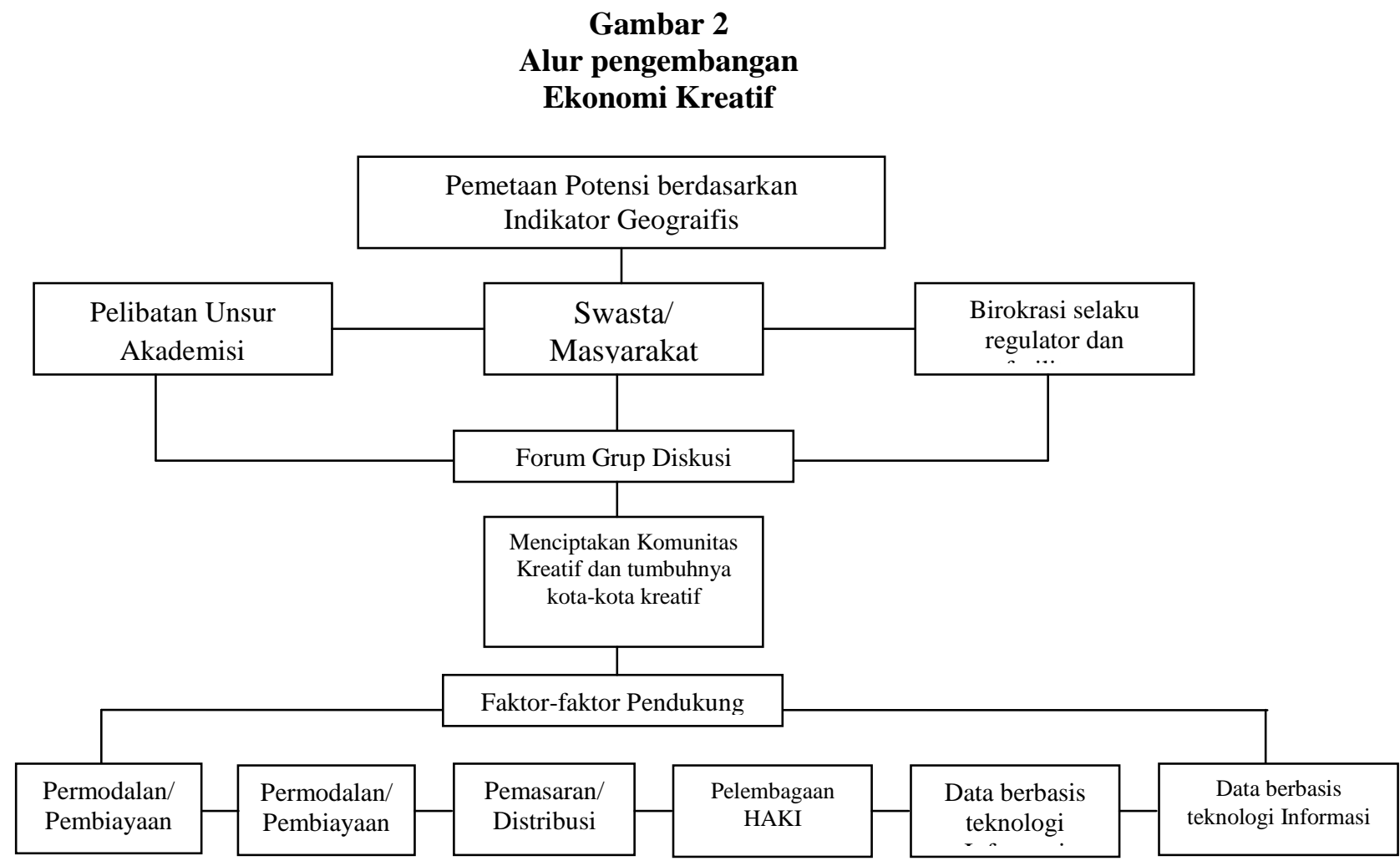

Sumber : Diolah Peneliti, 2017

\section{Hasil dan Simpulan}

Provinsi Banten memiliki modal dan potensi dari besaran ekspor produk-produk ekonomi kreatif, bahwa terdapat peluang-peluang yang dapat dimanfaatkan dan tantangan-tantangan yang perlu diatasi oleh stakeholder kebijakan ekonomi kreatif Provinsi Banten, perlunya penguatan sinergitas antara berbagai aktor ekonomi kreatif yaitu masyarakat, pemerintah, akademisi/intelektual, pelaku bisnis dan komunitas kreatif dalam mendorong pengembangan ekonomi kreatif di Provinsi Banten melalui sebuah inovasi model pengembangan kebijakan ekonomi kreatif. Melalui tata kelola ekonomi kreatif yang terintegrasi antara berbagai aktor-aktor kebijakan, penerapan strategis dan rencana aksi yang tepat sasaran maka tujuan pengembangan ekonomi kreatif sebagai lokomotiv penggerak perekonomian Banten dapat dicapai menuju terwujudnya Banten kreatif dan inovatif

Penguatan sinergitas antara berbagai aktor ekonomi kreatif yaitu pemerintah, akademisi/intelektual, komunitas kreatif dan pelaku bisnis dalam mendorong pengembangan ekonomi kreatif di Provinsi Banten. Melalui tata kelola ekonomi kreatif yang terintegrasi antara berbagai aktor-aktor kebijakan, penerapan strategis dan rencana aksi yang tepat sasaran maka tujuan ekonomi kreatif sebagai lokomotiv penggerak perekonomian Banten dapat dicapai menuju terwujudnya Banten kreatif dan inovatif.

\section{DAFTAR PUSTAKA}

Albury, 2003. dalam Handbook Inovasi Administrasi Negara.

Carlsson, L. and Sandstrom, A. (2008). "Network Governence in Commons". International Journal of the Commons. 2(1): 33-53. Igitur, Utrecht Publishing \& Archiving Services for IASC.

Deddy Mulyadi, 2015. Studi Kebijakan Publik dan Pelayanan Publik, Bandung, Alfabeta

Hamdan, 2016. Kebijakan Dan Strategi Pengembangan Ekonomi Kreatif, Studi Excursie Mahasiswa Jurusan Ilmu Ekonomi dan Studi Pembangunan Universitas Muhammadiyah Malang)

Herie Saksono, 2012. Ekonomi Kreatif: Talenta Baru Pemicu Daya Saing Daerah, Jurnal Bina Praja Volume 4 No. 2. 
Irawan. Andri. 2015. Ekonomi Kreatif Sebagai Suatu Solusi Mensejahterakan Masyarakat Dalam Meningkatkan Tingkat Perekonomian, Seminar Nasional Ekonomi dan Bisnis (SNEB)

Islamy, Irfan. : 2000. Prinsip-prinsip Perumusan Kebijaksanan Negara. Jakarta, Bumi Aksara

Kenis, P and Schneider, V 1991. "Policy Networks and Policy Analysis: Scrutinizing a New Analytical Toolbox". (1991) in B. Marin and R. Mayntz (eds) Policy Networks. Empirical Evidence and Theoretical Considerations. Frankfurt. Campus Verlag.

Kusumanegara, Solahudin, 2010. Model dan Aktor dalam Proses Kebijakan Publik. Yogyakarta, Gava Media

Lydia Wijayanti, 2012. Implementasi Kebijakan Pembangunan berkelanjutan di Kota Surakarta : Relokasi PKL di Taman Monumen Banjarsari ke pasar Klitikan Notoharjo, Jurnal Pembangunan Wilayah dan Kota, hal 129

Nugroho, Riant, 2004. Kebijakan Publik, Formulasi, implementasi dan evaluasi. Jakarta, Gramedia.

Romarina, Arina. 2016. Economic Resilience pada Industri Kreatf guna menghadapi globalisasi alam rangka ketahanan nasional, Jurnal Ilmu Sosial, Vol 15 No 1, Hal 35-52.

Simatupang dkk, 2008. Analisis Kebijakan Pengembangan Industri Kreatif di Kota Bandung. Jurnal Manajemen Teknologi, Volume 8 Number 1.

Suryana, 2013. Ekonomi Kreatif (Ekonomi Baru: Mengubah Ide dan Menciptakan Peluang). Jakarta: Salemba Empat.

UNCTAD. 2008. Summary Creative Economic Report. Hlm.3, 11 - 12. USA: United Nations

William N. Dunn, 2003. Pengantar Analisis Kebijakan Publik, Gadjah Mada University Press, Jogjakarta. 